\title{
PENGARUH PROMOSI MELALUI MEDIA SOSIAL TERH ADAP REPURCHASE INTENTION MELALUI ELECTRONIC WORD OF MOUTH
}

\author{
Eka Ayu Savitri \\ Zakiyah Zahara \\ Ponirin \\ Jurusan Manajemen, Fakultas Ekonomi, Universitas Tadulako \\ Email: ekaayu.savitri@yahoo.com
}

\begin{abstract}
This study aims to identify and analyze: (1) direct influence of promotion via social media on eWOM at RM Radja Penyet Mas Fais in Palu, (2) direct influence of promotion via social media on repurchase intention at RM Radja Penyet Mas Fais in Palu, (3) direct influence of eWOM to repurchase intention on RM Radja Penyet Mas Fais in Palu. Type of research is quantitative. The population consists of people who have been exposed information about RM Radja Penyet Mas Fais in social media, and had visited RM Radja Penyet Mas Fais or become followers @ radjapenyetmasfais instagram. Sampling technique is purposive sampling, with total sample of 100 respondents. Data collecting method using online and offline questionnaires that have been tested for their validity and reliability. The analytical method using path analysis. The results show that: (1) there is direct influence of promotion via social media on eWOM at RM Radja Penyet Mas Fais in Palu, (2) there is direct influence of promotion via social media on repurchase intention at RM Radja Penyet Mas Fais in Palu, (3) there is no direct influence of eWOM on repurchase intention at RM Radja Penyet Mas Fais in Palu.
\end{abstract}

Keywords: Promotion, Social Media, eWOM, repurchase intention.

\begin{abstract}
ABSTRAK
Penelitian ini bertujuan untuk mengetahui dan menganalisa: (1) Pengaruh langsung promosi melalui media sosial terhadap eWOM di RM Radja Penyet Mas Fais di Kota Palu, (2) Pengaruh langsung promosi melalui media sosial terhadap repurchase intention RM Radja Penyet Mas Fais di Kota Palu, (3) Pengaruh langsung eWOM terhadap repurchase intention di RM Radja Penyet Mas Fais di Kota Palu. Jenis penelitian yang digunakan adalah kuantitatif. Populasi penelitian ini adalah seluruh masyarakat umum yang pernah terpapar informasi mengenai RM Radja Penyet Mas Fais di media sosial, dan sudah pernah bersantap di RM Radja Penyet Mas Fais atau yang menjadi followers akun instagram @ radjapenyetmasfais.Teknik penarikan sampel dalam penelitian ini menggunakan purposive sampling, dengan jumlah sampel sebanyak 100 responden. Pengambilan data menggunakan kuesioner online dan offline yang telah diuji validitas dan reliabilitasnya. Metode analisis menggunakan path analysis. Hasil penelitian menunjukkan bahwa (1) Terdapat pengaruh langsung promosi melalui media sosial terhadap eWOM pada RM Radja Penyet Mas Fais di Kota Palu, (2) Terdapat pengaruh langsung promosi melalui media sosial terhadap repurchase intention pada RM Radja Penyet Mas Fais di Kota Palu, (3) Tidak Terdapat pengaruh langsung eWOM terhadap repurchase intention pada RM Radja Penyet Mas Fais di Kota Palu.
\end{abstract}

Kata Kunci: Promosi, Media sosial, eWOM, repurchase intention

\section{PENDAHULUAN}

Beralihnya pola konsumsi informasi tradisional menjadi digital karena kemudahan dalam memperoleh akses internet. Konsumen ingin selalu terhubung dengan dunia digital yang menyediakan berbagai jenis informasi yang selalu terbaharui secara real time. Seiring meningkatnya interaksi individu satu sama lain dengan menggunakan dunia digital, menjadikan dunia digital bukan hanya sekedar sebagai sarana komunikasi melainkan menjadi sarana perdagangan, yang dikenal sebagai $E$ commerece. 


\section{Savitri A.E.}

Menurut Kotler dan Keller (2016: 536), E-commerce uses a Web site to transact or facilitate the sale of products and services online. Maksudnya bahwa E-commerce menggunakan website untuk berinteraksi atau memfasilitasi penjualan produk atau jasa secara online. E-commerce merubah perilaku pembelian dari tradisional berbelanja di pasar, atau toko-toko menjadi hanya mengunjungi website dan memilih produk atau jasa yang ingin dibeli.

Menurut data yang ditulis situs http://www.internetworldstats.com jumlah pengguna internet di Indonesia sampai Juni 2016 sebesar 132.700.000 jiwa dari jumlah populasi sebesar 258.316.051 penduduk Indonesia. Data ini menunjukkan pertumbuhan penggunaan internet di Indonesia terus meningkat, terutama dibandingkan dengan hasil riset APJII (Asosiasi Penyelenggara Jasa Internet Indonesia) mengenai hal yang sama di tahun 2012. Dalam penelitian mengenai profil pengguna internet di Indonesia tahun 2012, APJII melaporkan penetrasi pengguna internet di Indonesia adalah 24,23\% (APJII,2012). Sementara survey internerworldstats.com di tahun 2016 menunjukkan penetrasi pengguna internet di Indonesia adalah 51.4\%.

Promosi melalui internet khususnya dengan media sosial (social media marketing) dapat meningkatkan penjualan secara luas dan tidak memerlukan biaya pemasaran yang mahal. Menurut Kotler dan Keller dalam buku Marketing Management Global Edition, media sosial berbasis internet sering disebut juga dengan situs jejaring sosial. Situs jejaring sosial dalam bahasa Inggris disebut social networks, yang merupakan sebuah web berbasis pelayanan yang memungkinkan penggunanya untuk membuat profil, melihat daftar pengguna yang tersedia, serta mengundang atau menerima teman untuk bergabung dalam situs tersebut. Keberadaan jejaring sosial mengakibatkan konsumen juga akan lebih mudah untuk mencari informasi mengenai produk yang ingin mereka beli karena tidak perlu tatap muka secara langsung.

Hasil riset APJII 2012, menunjukan dari tujuh lokasi penjualan online (forum jual beli, jejaring sosial, mailing list, blog, domain, messenger dan komunitas online), yang paling banyak digunakan oleh pengguna internet di Indonesia adalah jejaring sosial (media sosial).

Data yang ditulis dari situs http://Techno.id menunjukan top platform media sosial dan aplikasi sosial terpopuler di Indonesia tahun 2016 yang dihasilkan oleh lembaga survey WeAreSocial, Facebook masih menjadi media sosial favorite, disusul Instagram dan Twitter.

Hasil survey yang sama juga ditulis dalam situs http://www. internetworldstates.com (2016) bahwa, Facebook masih menjadi media sosial yang paling banyak digunakan di Indonesia. Riset ini menunjukan, sekitar 88.000.000 juta pengguna aktif Facebook di Indonesia sampai bulan Juni 2016 dengan jumlah penetrasi sebesar $34,1 \%$.

Melihat banyaknya pengakses media sosial di Indonesia melalui smarthphones, bisa menjadi peluang bisnis yang baik, salah satunya di bidang usaha kuliner. Salah satu perusahaan yang bergerak di bidang kuliner adalah RM Radja Penyet Mas Fais yang memilih mempromosikan produknya melalui akun Facebook dan akun Instagramnya. Para konsumen umumnya mengetahui produk-produk dari RM Radja Penyet Mas Fais melalui info Facebook atau dari tag foto-foto produknya di Instagram. Walaupun produknya hanya dipromosikan lewat media sosial tetapi para konsumennya sudah tersebar luas.

Tidak dapat dipungkiri media sosial yang saat ini sering digunakan untuk memasarkan produk antara lain adalah Facebook dan Instagram cukup terkenal di Indonesia. Dengan media sosial tersebut akan terbentuk komunikasi pemasaran yang efektif secara online yaitu electronic word of mouth (eWOM). Jalilvand (2012), menjelaskan eWOM menjadi sebuah "venue" atau sebuah tempat yang sangat penting untuk konsumen memberikan opininya dan dianggap lebih efektif dibandingkan WOM karena tingkat aksesibilitas dan jangkauannya yang lebih luas daripada WOM tradisional yang bermedia offline. Hal ini dikarenakan electronic word of mouth (eWOM) muncul secara natural dari pendapat lingkungan sosial yang dirasa lebih jujur dan tidak ada motif-motif tertentu dalam 
menyampaikan suatu informasi kepada konsumen lainnya. Tujuan penelitian ini adalah untuk mengetahui dan menganalisa:

1. Pengaruh langsung promosi melalui media sosial terhadap electronic word of mouth (eWOM) di RM Radja Penyet Mas Fais di Kota Palu.

2. Pengaruh langsung promosi melalui media sosial terhadap repurchase intention RM Radja Penyet Mas Fais di Kota Palu.

3. Pengaruh langsung electronic word of mouth (eWOM) terhadap repurchase intention di RM Radja Penyet Mas Fais di Kota Palu.

\section{KAJIAN LITERATURE DAN PENGEMBANGAN HIPOTESIS Bauran Pemasaran (Marketing Mix)}

Pengertian bauran pemasaran menurut Kotler dan Amstrong (2012: 92) "Marketing mix is good marketing tool is a set of products, pricing, promotion, distribution, combined to produce the desired response of the target market". Dalam bauran pemasaran terdapat seperangkat alat pemasaran yang dikenal dalam istilah 4P, yaitu product (produk), price (harga), place (tempat atau saluran distribusi), dan promotion (promosi), sedangkan dalam pemasaran jasa memiliki beberapa alat pemasaran tambahan seperti people (orang), physical evidence (fasilitas fisik), dan process, sehingga dikenal dengan istilah 7P.

\section{Promosi}

Promosi merupakan elemen dari marketing mix communications yang digunakan oleh perusahaan untuk menginformasikan produk atau jasanya. Wilmshurst (1993) dalam Dave chaffy et al (2003:208) menjelaskan:

Promotion unfortunately has a range of meanings. It can be used to describe the marketing communications aspect of the marketing mix or, more narrowly, as is sales promotion. In its very broad sense it includes the personal methods of communications, such as face to face or telephone selling, as well as the impersonal ones such advertising. When we use a range of different types of promotion - direct mail, exhibitions, publicity etc. we describe it as the promotional mix.

Selanjutnya menurut Kotler dan Keller (2016:582) agar perusahaan mencapai tujuan dari komunikasi, perusahaan dapat menggunakan alat bantu yang terdiri dari delapan model komunikasi, yaitu:
1. Advertising
2. Sales Promotion
3. Event and experiences
4. Public Relations and Publicity
5. Online and social media marketing
6. Mobile marketing
7. Direct and database marketing
8. Personal Selling

\section{Perilaku Konsumen}

Menurut Engel et al (2006) dalam Sangadji (2013: 8) mendefinisikan perilaku konsumen sebagai tindakan yang langsung terlibat dalam pemerolehan, pengonsumsian, dan penghabisan produk dan jasa, termasuk proses keputusan yang mendahului dan menyusuli tindakan ini. Subjek ini dapat diancangi dari beberapa perspektif yang semuanya dipertimbangkan, yaitu: 1) pengaruh konsumen (consumer influence); 2) menyeluruh (wholistic); dan 3) antarbudaya (intercultural). 


\section{Savitri A.E.}

Kotler (2005) dalam Sangadji (2013: 8) menjelaskan perilaku konsumen sebagai suatu studi tentang unit pembelian bisa perorangan, kelompok, atau organisasi. Masing-masing unit tersebut akan membentuk pasar sehingga muncul pasar individu atau pasar konsumen, unit pembelian kelompok, dan pasar bisnis yang dibentuk organisasi.

McKechnie (2012) dalam Sangadji (2013: 9) mendefenisikan The field of Consumen Behavior: "Studies how individuals, groups, and organizations select, buy, use, and dispose of goods, services, ideas, or experiences to satisfy their needs and desires."

Berdasarkan tiga pengertian di atas, dapat disimpulkan bahwa perilaku konsumen adalah tindakantindakan yang dilakukan oleh individu, kelompok, atau organisasi yang berhubungan dengan proses pengambilan keputusan dalam mendapatkan, menggunakan barang-barang atau jasa ekonomis yang dapat dipengaruhi lingkungan.

\section{Repurchase Intention}

Minat membeli ulang terjadi setelah konsumen melakukan pembelian, dapat dikarenakan pernah mengkonsumsi sehingga berminat lagi untuk membeli ulang produk atau jasa yang sama. Hellier, Philip, Geursen, Carr, and Rickard (2003) dalam Prastyaningsih (2014: 4) memberikan definisi "repurchase intentionis the individual's judgement about buying again a designated service from the same company, taking into account his or her current situation and likely circumstance". Oleh karena itu, repurchase intention (minat beli ulang) dapat disimpulkan bahwa repurchase intention merupakan hasrat atau keinginan yang timbul dalam diri konsumen untuk membeli produk atau jasa yang disukainya dan sebelumnya pernah membelinya berdasarkan hasil evaluasi atas kesesuaian kinerja produk atau jasa dengan harapan konsumen.

Terdapat beberapa faktor yang dapat mempengaruhi konsumen dalam minat pembelian, baik faktor internal dan eksternal. Faktor internal dari dalam diri konsumen yakni kepercayaan dan sikap konsumen terhadap produk atau jasa, sedangkan faktor pengganggu dari eksternal adalah sikap orang lain serta situasi tempat pembelian (Kotler, 2008: 242).

\section{Media sosial}

Media sosial adalah fitur berbasis website yang dapat membentuk jaringan serta memungkinkan orang untuk berinteraksi dalam sebuah komunitas. Pada media sosial kita dapat melakukan berbagai bentuk pertukaran, kolaborasi, dan saling berkenalan dalam bentuk tulisan visual maupun audiovisual. Contohnya seperti Facebook, Twitter dan Instagram (Puntoadi, 2011:1), sedangkan menurut Kotler dan Keller (2016:642) "social media are a means for consumers to share text, images, audio, and video information with each other and with companies, and vice versa". Maksudnya media sosial merupakan sarana bagi konsumen untuk berbagi teks, gambar, dan video informasi dengan satu sama lain dan dengan perusahaan dan sebaliknya. Kotler dan Keller (2016: 643) membagi tiga platform utama media sosial yaitu:

\section{Online communities and forums}

2. Blog-gers

3. Social networks

\section{Electronic Word of Mouth (eWOM)}

Word of Mouth online adalah proses word of mouth dengan menggunakan media internet. Dengan aktivitas dalam $e W O M$, konsumen akan mendapatkan tingkat transparansi pasar yang tinggi, dengan kata lain konsumen memiliki peran aktif yang lebih tinggi dalam siklus rantai nilai sehingga konsumen mampu mempengaruhi produk dan harga berdasarkan preferensi individu (Park dan Kim, 2008).

Goyette, et al., (2010) membagi e-WOM dalam tiga dimensi yaitu : 
a. Content

Adalah isi informasi dari media sosial berkaitan dengan produk dan jasa. Indikator dari Content meliputi :

1) Informasi variasi makanan dan minuman.

2) Informasi kualitas (rasa, tekstur dan suhu) makanan dan minuman. 3) Informasi mengenai harga yang ditawarkan.

b. Negative Valence of Opinion

Adalah pendapat konsumen negatif mengenai produk, jasa dan brand.

c. Positive Valence of Opinion

Adalah pendapat konsumen positif mengenai produk, jasa dan brand. $\mathrm{d}$.

\section{Intensity}

Intensity (intensitas) dalam eWOM adalah banyaknya pendapat yang ditulis oleh konsumen dalam sebuah situs jejaring sosial. Penelitian yang dilakukan oleh Goyette, et al., (2010) membagi indikator intensity sebagai berikut:

1) Frekuensi mengakses informasi dari media sosial.

2) Frekuensi interaksi dengan pengguna media sosial.

3) Banyaknya ulasan yang ditulis oleh pengguna media sosial

\section{Kerangka Pemikiran}

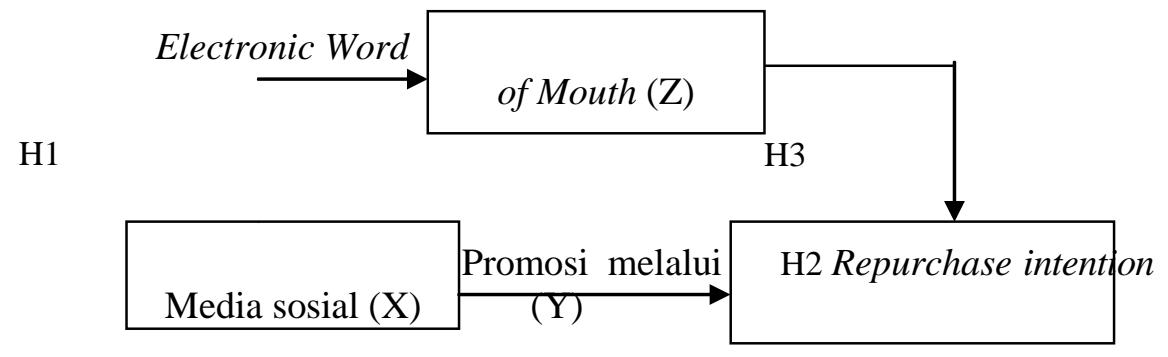

Gambar 1. Kerangka pemikiran

\section{Hipotesis}

Berdasarkani teori dan kerangka berpikir diatas dapat disusun beberapa hipotesis sebagai berikut:

1. Terdapat pengaruh langsung promosi melalui media sosial terhadap electronic word of mouth (eWOM) pada RM Radja Penyet Mas Fais di Kota Palu.

2. Terdapat pengaruh langsung promosi melalui media sosial terhadap Repurchase intention pada RM Radja Penyet Mas Fais di Kota Palu.

3. Terdapat pengaruh langsung electronic word of mouth (eWOM) terhadap Repurchase intention pada RM Radja Penyet Mas Fais di Kota Palu.

\section{METODE PENELITIAN}

Berdasarkan klasifikasi tujuannya, penelitian ini termasuk ke dalam jenis kuantitatif karena penelitian ini bersifat menunjukan hubungan antar variabel (Sugiyono 2014:54). Peneliti melakukan survei untuk mengambil data di lapangan. Teknik pengumpulan data dengan pengamatan (wawancara atau kuesioner) yang tidak mendalam, dan hasil penelitian cenderung untuk digeneralisasikan.

Variabel-variabel dalam penelitian ini adalah:

1. Variabel bebas (Independent Variable)

Variabel bebas (X) dalam penelitian ini adalah promosi melalui media sosial. Pengukuran media sosial ini menggunakan 4 indikator yaitu: context (konteks), communications (komunikasi), collaboration (kolaborasi), connections (koneksi) (Solis 2010: 263). 


\section{Savitri A.E.}

\section{Variabel Mediasi (Penghubung)}

Variabel Mediasi $(\mathrm{Z})$ atau mediating variable adalah variabel yang mempengaruhi fenomena yang diobservasi (variabel dependen). Variabel mediasi dalam penelitian ini adalah electronic word of mouth (eWOM). Menurut penelitian Goyette (2010), komunikasi word of mouth dalam konten elektronik dapat diukur dengan indikator sebagai berikut word of mouth content (konten komunikasi dari mulut ke mulut), negative valence word of mouth (komunikasi dari mulut ke mulut negatif), positive valence word of mouth (komunikasi dari mulut ke mulut positif), word of mouth intensity (intensitas komunikasi dari mulut ke mulut).

\section{Variabel Terikat (Dependent Variable)}

Variabel terikat $(\mathrm{Y})$ pada penelitian ini adalah repurchase intention pada RM Radja Penyet Mas Fais yang terdiri dari beberapa indikator, yaitu: adanya minat pelanggan untuk berkunjung kembali, minat pelanggan untuk mengunjungi restoran dengan frekuensi yang lebih sering, minat pelanggan untuk merekomendasikan kepada orang lain, minat pelanggan untuk membawa teman/keluarga, serta menjadikan restoran sebagai pilihan pertama dibandingkan dengan restoran lain yang sejenis.

Populasi penelitian ini adalah seluruh masyarakat umum yang pernah terpapar informasi mengenai RM Radja Penyet Mas Fais di media sosial, dan sudah pernah bersantap di RM Radja Penyet Mas Fais atau yang menjadi followers akun instagram @ radjapenyetmasfais. Teknik pengambilan sampel untuk menentukan sampel yang akan digunakan dalam penelitian ini menggunakan Teknik non probability sampling, yaitu purposive sampling.

Unit sampel dalam penelitian ini adalah konsumen yang menjadi followers @ radjapenyetmasfais. Populasinya merujuk pada jumlah followers akun Instagram @ radjapenyetmasfais pada tanggal 02 Desember 2016 yaitu 5.590 orang. Berdasarkan jumlah populasi tersebut untuk mengetahui besaran sampel dapat menggunakan rumus Yamane (Riduwan, 2007:210). Dari hasil perhitungan tersebut maka didapatkan 98 responden dan dibulatkan menjadi 100 untuk memudahkan peneliti dalam melakukan perhitungan.

Penelitian ini menggunakan aplikasi software SPSS (Statistical Program for Social Scane) versi 16.0 yang dipakai untuk menganalisis pengaruh langsung maupun tidak langsung promosi melalui media sosial terhadap repurchase intention yang dimediasi electronic word of mouth. Adapun teknik analisis data yang dipergunakan dalam penelitian ini, yaitu analisis jalur. Riduwan dan Kuncoro (2007:2) model analisis jalur (path analysis) digunakan untuk menganalisis pola hubungan antar variabel dengan tujuan untuk mengetahui pengaruh langsung maupun tidak langsung seperangkat variabel bebas (eksogen) terhadap variabel terikat (endogen). persamaan struktural dalam model analisis jalur ini adalah sebagai berikut:

$\mathrm{Y}=\rho \mathrm{xZ}+\varepsilon_{1}$

$Z=\rho x Y+\rho z y+\varepsilon_{2}$ 


\section{HASIL DAN PEMBAHASAN}

Analisis Jalur (path analysis)

Tabel 1 Hasil Regresi Persamaan Struktural Pertama

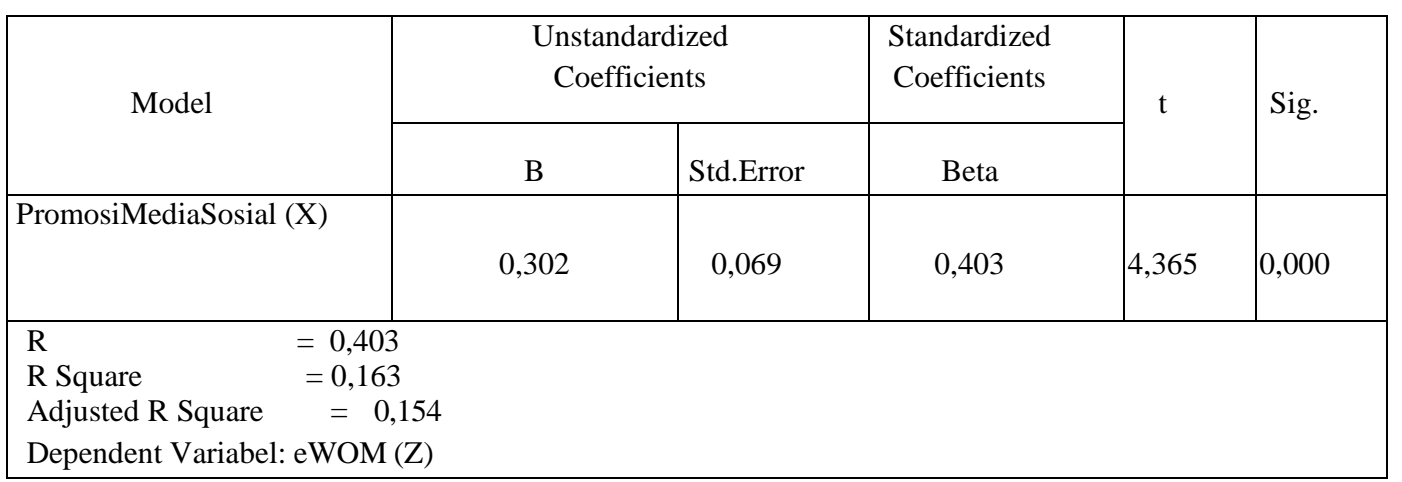

Pengaruh kesalahan pengganggu atau error variabel $\left(\rho \varepsilon_{1}\right)$ untuk persamaan struktural pertama diperoleh:

$$
\begin{aligned}
P E 1= & \sqrt{1-R^{2}} \\
& \sqrt{1-0,163}
\end{aligned}
$$

$=0,914$

Dengan demikian, persamaan struktural pertama diperoleh:

$\mathrm{Z}=\mathbf{0 , 4 0 3 X}+\mathbf{0 , 9 1 4} \varepsilon_{1}$

\begin{tabular}{|c|c|c|c|c|c|}
\hline \multirow{2}{*}{ Model } & & $\begin{array}{l}\text { Unstandardized } \\
\text { Coefficients }\end{array}$ & \multirow{2}{*}{$\begin{array}{c}\text { Standardized } \\
\text { Coefficients }\end{array}$} & \multirow{2}{*}{$\mathrm{t}$} & \multirow{2}{*}{ Sig. } \\
\hline & B & Std.Error & & & \\
\hline $\begin{array}{l}\text { PromosiMediaSosial } \\
\text { eWOM }\end{array}$ & $\begin{array}{l}0,654 \\
0,047\end{array}$ & $\begin{array}{l}0,075 \\
0,100\end{array}$ & $\begin{array}{l}0,688 \\
0,037\end{array}$ & $\begin{array}{l}8,720 \\
0,470\end{array}$ & $\begin{array}{l}0,000 \\
0,640\end{array}$ \\
\hline $\begin{array}{l}\mathrm{R} \\
\mathrm{R} \text { Square } \\
\text { Adjusted R Square } \\
\text { Dependent Variabel: }\end{array}$ & $\begin{array}{l}=0,703 \\
=0,495 \\
=0,484 \\
\text { RepurchaseIntentio }\end{array}$ & & & & \\
\hline
\end{tabular}

Tabel 2 Hasil Regresi Persamaan Struktural Kedua

Pengaruh kesalahan pengganggu atau error variabel $\left(\rho \varepsilon_{2}\right)$ untuk persamaan struktural kedua diperoleh:

$$
\begin{aligned}
\mathrm{P} \varepsilon= & \frac{\sqrt{1-R^{2}}}{\sqrt{1-0,495}} \\
= & 0,710
\end{aligned}
$$

Dengan demikian, persamaan struktural kedua diperoleh:

$Y=0,688 X+0,037 Y+0,710 \varepsilon_{2}$ 
Savitri A.E.

Tabel 3 Hasil Pengujian Koefisien Jalur (standardized coefficients)

\begin{tabular}{|c|c|c|c|}
\hline $\begin{array}{c}\text { Hubungan Kausalitas } \\
\text { Variabel }\end{array}$ & $\begin{array}{c}\text { Koefisien Jalur } \\
\text { (Beta) }\end{array}$ & $\begin{array}{c}\text { Nilai Sig. } \\
\text { (pvalue) }\end{array}$ & Interpretasi \\
\hline $\mathrm{X} \rightarrow \mathrm{Z}$ & 0,403 & 0,000 & Signifikan \\
\hline $\mathrm{X} \rightarrow \mathrm{Y}$ & 0,688 & 0,000 & Signifikan \\
\hline $\mathrm{Y} \rightarrow \mathrm{Z}$ & 0,037 & 0,640 & $\begin{array}{c}\text { Tidak } \\
\text { Signifikan }\end{array}$ \\
\hline
\end{tabular}

\section{Pembahasan}

a) Pengujian Hipotesis Pertama (H1)

Hipotesis pertama $(\mathrm{H} 1)$ dalam penelitian ini menyatakan "Promosi melalui media sosial berpengaruh langsung terhadap $\boldsymbol{e W O M " . ~ B e r d a s a r k a n ~ h a s i l ~ a n a l i s i s ~ p a d a ~ j a l u r ~ p r o m o s i ~}$ media sosial diperoleh nilai koefisien jalur sebesar 0,403 dengan nilai sig. 0,000 lebih kecil dari $0,05(0,000<0,05$, signifikan). Hasil analisis ini menunjukan bahwa promosi media sosial berpengaruh langsung, positif, dan signifikan terhadap eWOM. Dengan demikian hipotesis pertama (H1) dinyatakan diterima.

b) Pengujian Hipotesis Kedua (H2)

Hipotesis kedua $(\mathrm{H} 2)$ dalam penelitian ini menyatakan "Promosi melalui media sosial berpengaruh langsung terhadap repurchase intention". Berdasarkan hasil analisis pada jalur $e W O M$ diperoleh nilai koefisien jalur sebesar 0,688 dengan nilai sig. 0,000 lebih kecil dari $0,05(0,000<0,05$, signifikan). Hasil analisis ini menunjukan bahwa promosi media sosial berpengaruh langsung, positif, dan signifikan terhadap repurchase intention. Dengan demikian hipotesis kedua $(\mathrm{H} 2)$ dinyatakan diterima.

c) Pengujian Hipotesis Ketiga (H3)

Hipotesis ketiga $(\mathrm{H} 3)$ dalam penelitian ini menyatakan "eWOM berpengaruh langsung terhadap repurchase intention". Berdasarkan hasil analisis pada jalur repurchase intention diperoleh nilai koefisien jalur sebesar 0,037 dengan nilai sig. 0,640 lebih besar dari 0,05 $(0,640>0,05$, tidak signifikan). Hasil analisis ini menunjukan bahwa eWOM tidak berpengaruh langsung dan tidak signifikan terhadap repurchase intention. Dengan demikian hipotesis ketiga (H3) dinyatakan ditolak.

\section{Pengujian Pengaruh Tidak Langsung}

Berdasarkan hasil analisis pada jalur promosi media sosial terhadap eWOM diperoleh nilai koefisien jalur sebesar 0,403 dan nilai sig.0,000 $(0,000<0,05$, signifikan). Sedangkan hasil analisis jalur eWOM terhadap repurchase intention diperoleh nilai koefisien jalur sebesar 0,037 dan nilai sig. $0,640(0,640>0,05$, tidak signifikan). Salah satu kedua jalur tersebut mempunyai pengaruh langsung yang tidak signifikan, sehingga dapat dinyatakan bahwa tidak terdapat pengaruh tidak langsung promosi media sosial $(\mathrm{X})$ terhadap repurchase intention $(\mathrm{Y})$ melalui eWOM $(\mathrm{Z})$. Besarnya pengaruh tidak langsung sebesar: $(0,403)(0,037)=0,014$ atau $(0,014)^{2}=0,019 \%$, sedangkan sisanya sebesar $99,81 \%$ dipengaruhi oleh faktor lain yang tidak termasuk dalam penelitian ini. Selanjutnya, hasil perhitungan Sobel-Test dengan memanfaatkan online statistics calculators (http://danielsoper.com) diperoleh nilai $\mathrm{Z}$ sebesar $0,051<1,98$ dengan tingkat signifikansi $5 \%$ maka membuktikan bahwa eWOM (Z) tidak mampu memediasi hubungan promosi media sosial $(\mathrm{X})$ terhadap repurchase intention $(\mathrm{Y})$ atau tidak terdapat pengaruh tidak langsung promosi media sosial $(\mathrm{X})$ terhadap repurchase intention (Y) melalui eWOM (Z).

\section{KESIMPULAN DAN SARAN}

\section{Kesimpulan}

1. Terdapat pengaruh langsung promosi melalui media sosial terhadap electronic word of mouth (eWOM) pada RM Radja Penyet Mas Fais di Kota Palu. Besarnya pengaruh promosi media sosial terhadap eWOM sebesar $16,2 \%$, sedangkan sisanya sebesar $83,8 \%$ dipengaruhi oleh faktor lain yang tidak termasuk dalam penelitian.

2. Terdapat pengaruh langsung promosi melalui media sosial terhadap repurchase intention pada RM Radja Penyet Mas Fais di Kota Palu. Besarnya pengaruh promosi media sosial terhadap repurchase 
intention sebesar repurchase intention dipengaruhi oleh promosi melalui media sosial sebesar $47,3 \%$, sedangkan sisanya sebesar $52,7 \%$ dipengaruhi oleh faktor lain yang tidak termasuk dalam penelitian.

3. Tidak terdapat pengaruh langsung electronic word of mouth (eWOM) terhadap repurchase intention pada RM Radja Penyet Mas Fais di Kota Palu. Besarnya pengaruh eWOM terhadap repurchase intention sebesar $0,13 \%$, sedangkan sisanya sebesar $99,87 \%$ dipengaruhi oleh faktor lain yang tidak termasuk dalam penelitian.

\section{Saran}

1. Peneliti menyarankan RM Radja Penyet Mas Fais untuk selalu melakukan promosi secara terus menerus dan memperbaharui konten media sosial dengan inovasi tampilan yang menarik agar konsumen yang melihat tidak merasa bosan. Selain itu, RM Radja Penyet Mas Fais juga dapat menambahkan media sosial lain untuk sarana promosi seperti aplikasi chatting (BBM, Whatsup, Line) dan Facebook Ads agar promosi yang dilakukan lebih efektif lagi.

2. Peneliti juga menyarankan untuk meningkatkan intensitas $e W O M$ karena $e W O M$ adalah satusatunya metode promosi yang berasal dari konsumen, oleh konsumen, dan untuk konsumen. Jadi hal ini sangat perlu diperhatikan mengingat informasi yang tersebar antar individu tentang RM Radja Penyet Mas Fais, baik informasi positif maupun negatif keduanya dapat mempengaruhi keinginan konsumen. Informasi yang baik akan memberikan dampak yang baik, sebaliknya informasi yang buruk akan menghambat tindakan seseorang dalam melakukan repurchase intention. Sehingga dalam hal ini RM Radja Penyet Mas Fais harus memperhatikan setiap hal yang mereka tawarkan kepada konsumen, baik dari segi produk, konsep dan layanan yang diberikan. Hal-hal tersebut harus diperhatikan karena, setiap kepuasan atau pun kekecewaan seorang konsumen terhadap RM Radja Penyet Mas Fais dapat menjadi sebuah bahan perbincangan antar individu. Kepuasan konsumen akan menjadi sebuah informasi yang baik yang dapat menguntungkan bagi RM Radja Penyet Mas Fais, sedangkan kekecewaaan konsumen akan menjadi sebuah informasi yang buruk dan dapat merugikan RM Radja Penyet Mas Fais.

3. Disarankan RM Radja Penyet Mas Fais untuk cepat dalam menanggapi jika tercipta negative valance eWOM, dengan melakukan sesuatu hal yang dapat membuat konsumen yang sebelumnya merasakan kekecewaan menjadi senang kembali, sehingga bisa melakukan repurchase intention secara terus menerus. Misalnya, dengan memberikan potongan harga, free biaya delivery, ataupun tambahan extra porsi untuk konsumen yang pernah merasakan kekecewaan.

\section{REFERENSI}

Chaffy, Dave., et al. 2003. Internet marketing: Strategy, Implementation, and practice. ${ }^{n d}$ edition. England: Prentice Hall.

Goyette, I., Richard, L., Bergeron, J. Dan Marticotte, F (2010). E-WOM Scale: Word-of-Mouth Measurement Scale for e-Services Context, Canadian Journal of Administration Sciences, 27(1),5-23.

Jalilvand, M,R.(2012). "The Effect of Electronic Word-Of-Mouth on Brand Image and Purchase Intention". Journals Of Marketing Inteligence And Planning. Vol.30, Iss:4, hal.5-5.

Kotler, P. \& Keller, Kevin Lane. 2016. Marketing management. $15^{\text {th }}$ edition. England: pearson education, Inc.

Kotler,P. \& Keller, Kevin Lane. 2012. Marketing management 14e. England: pearson education, Inc.

Kotler, Philip dan Keller, Kevin Lane. 2008.ManajemePemasaran..Diterjemahkan oleh Benyamin MolanEdisi Keduabelas. Jakarta: PT Indeks

Puntoadi, Danis. 2011. Menciptakan Penjualan Melalui Social media. Jakarta: PT. Elex Media Komputindo.

Prastyaningsih, Ayu Sari \& Imam Suyadi \& Edy Yulianto. (2014). Pengaruh Customer Experience terhadap Repurchase Intention (Niat Membeli Ulang). Jurnal Administrasi Bisnis (JAB) Vol. 16 No. 1 November. Universitas Brawijaya, Malang.

Riduwan \& Engkos Ahmad Kuncoro. 2007. Cara menggunakan dan memaknai Analisis Jalur (path analysis). Bandung: Alfabeta.

Sangadji \& Sopiah. 2013. Perilaku konsumen. Yogyakarta: Cv. Andi offset. 


\section{Savitri A.E.}

Sugiyono. (2014). Metode penelitian manajemen: Pendekatan Kuantitatif,

Kualitatif, Kombinasi, Penelitian Tindakan dan Penelitian Evaluasi, Cetakan Ke-3, Bandung: Alfabeta.

Solis, Brian. (2010). Engage: The Complete Guide for Brands and Businesses to Build

Cultivate and Measure Success on The Web. New Jersey: John Wiley \& Sons.

Sumber internet:

http://www.Apjii.or.id (diakses 26 Juli 2016) http://womma.org (diakses 16 Oktober 2016) http://www.internetworldstats.com (diakses 4 Januari 2017) http://www.Techno.id (diakses 4 Januari 2017) http://danielsoper.com) (diakses 12 Maret 2017) 